\title{
Quality of life and health of breast cancer woman survivors in Popayan-Colombia
}

\author{
Calidad de vida y salud en mujeres sobrevivientes al cáncer de mama en Popayán- \\ Colombia
}

\section{Qualidade de vida e saúde em mulheres sobreviventes ao câncer de mama em Popayán, Colômbia}

Nancy Janneth Molano-Tobar*

Maite del Pilar Rada-Mendoza**

\begin{abstract}
Autor de correspondencia
* $\triangle$ Physiotherapist, Master in Sport Physiology, $\mathrm{PhD}$ candidate in Biomedical Sciences. Professor. Universidad del Cauca. Email: najamoto@unicauca.edu.co. Orcid: https://orcid.org/0000-00031953-4101. Popayán, Colombia

**Chemistry, Master in Chemistry, $\mathrm{PhD}$ in in Food Science and Technology. Professor Universidad del Cauca. Email: mrada@unicauca.edu.co. Orcid: https://orcid.org/0000-0003-1456-1653. Popayán, Colombia.
\end{abstract}

(C) Universidad Francisco de Paula Santander. Este es un artículo bajo la licencia CC BY (https://creativecommons.org/ licenses/by/4.0/) @) ()

\begin{abstract}
Objective: Identify the quality of life and its association with health parameters for breast cancer women survivors in Popayan, Colombia. Methods: Analytic crosssectional descriptive correlated study, with nonprobability sampling, according to the inclusion criteria of 39 women who survived breast cancer, who received a survey made by the authors which included sociodemographic aspects, evaluation of the quality of life through the questionnaire EORTC QLQ - BR23 and measurements such as the Body Mass Index (BMI), blood pressure and blood sugar levels, according to international standards. Results: The health indicators (blood pressure and blood sugar) are found under the normal ranges, while the BMI has a tendency for overweight. Regarding quality of life, high measurements for body image and sexual function were evidenced, while the dimensions of sexual pleasure and future perception showed intermediate measures. Regarding association, moderate correlations were observed between blood pressure and blood sugar levels, with body image and the sexual aspect. Conclusions: An association between the health indicators and the quality of life was observed, demonstrating the need to formulate prevention and intervention actions from an interdisciplinary vision. Also, it was observed that the quality of life requires a review toward self-confidence and relationship with oneself, through workshops or talks that allow to overcome limitations proper of the disease and to move on.
\end{abstract}

Keywords: Quality of life, breast cancer, women, blood pressure, blood sugar, EORTC QLQ - BR23.

\section{Resumen}

Objetivo: Identificar la calidad de vida y su asociación con parámetros de salud en mujeres sobrevivientes al cáncer de mama en Popayán, Colombia. Métodos: Estudio descriptivo-correlacional de corte transversal analítico, con una muestra no probabilística, de acuerdo con criterios de inclusión de 39 mujeres sobrevivientes al cáncer, a quienes se 
les aplicó una encuesta de elaboración propia con aspectos socio-demográficos, valoración de la calidad de vida mediante el cuestionario EORTC QLQ - BR23 y mediciones como el Índice de Masa corporal (IMC), presión arterial y niveles de glucemia, según estándares internacionales. Resultados: Los índices de salud (presión arterial y glucemia) se encontraron bajo los rangos de normalidad, mientras que para IMC hay tendencia de sobrepeso. Respecto a la calidad de vida, se evidenciaron mediciones elevadas para la imagen corporal y la función sexual, mientras que las dimensiones de disfrute sexual y percepción a futuro presentaron mediciones intermedias. Respecto a la asociación, se observaron correlaciones moderadas entre la presión arterial y los niveles de glucemia, con la imagen corporal y la parte sexual. Conclusiones: Se evidenció una asociación entre los indicadores de salud y calidad de vida, demostrando la necesidad de plantear acciones de prevención e intervención desde una visión interdisciplinaria. De la misma manera, se observó que la calidad de vida requiere una revisión hacia la autoconfianza y relación consigo misma, a través de talleres o charlas que permitan superar las limitaciones propias de la enfermedad y salir adelante.

Palabras clave: Calidad de vida, cáncer de mama, mujer, presión arterial, glucemia, EORTC QLQ - BR23.

\section{Resumo}

Objetivo: Identificar a qualidade de vida e a sua associação com parâmetro de saúde em mulheres sobreviventes ao câncer de mama em Popayán, Colômbia. Métodos: Estudo descritivo-correlacional de corte transversal analítico, estudando uma a mostra probabilística de 39 mulheres sobreviventes ao câncer de mama, que responderam um instrumento de formulação própria com aspectos sociais e demográficos, avaliação da qualidade de vida empregando o questionário EORTC QLQ - BR23 e foram estabelecidos o índice de massa corporal (IMC), a pressão arterial e níveis de glicemia segundo padrões internacionais. Resultados: Os níveis de pressão arterial e glicemia encontraram-se nos rangos de normalidade, entretanto, o IMC mostrou a tendência ao sobrepeso. Na aferição da qualidade de vida, observaram-se medições elevadas na imagem corporal e função sexual, enquanto que as dimensões desfrute sexual e percepção do futuro presentaram aferições intermediarias. Na associação de variáveis houve uma moderada relação entre a pressão arterial e os níveis de glicemia com a imagem corporal e a parte sexual. Conclusões: Evidenciou-se a associação entre os indicadores de saúde e a qualidade de vida, demostrando a necessidade de formular ações de prevenção e intervenção desde uma perspectiva interdisciplinar. Do mesmo modo, observou-se que a qualidade de vida requer uma revisão dirigida à autoconfiança e relação com se mesma, através de oficinas ou conferencias que permitam superar as limitações próprias da doença e seguir em frente.

Palavras-chave: Qualidade de vida, neoplasias da mama, mulheres, pressão arterial, glicemia EORTC QLQ - BR23.

\section{Introduction}

Cancer as the third cause of death in developed countries, is currently recognized as a global pandemic (1), as well as some cardiovascular diseases and diabetes, which have increased their mortality rates (2). The World Health Organization (WHO), mentions that it globally represents $16 \%$ of all the cancers for women and is the most common neoplasm both in developed and emerging countries (3), a situation that must be intervened from the diverse health areas.

In Colombia, the mortality tendency has been rising, causing almost $50 \%$ of breast cancer defunctions to women in the health system(4), implying on a social level a responsibility in public health and in the immediate family members. The above-mentionedcan be explained as cancer practically being a sex disease and women being the central figure for the family. This type of cancer is the most frequent, and which development is associated to factors such as: unhealthy lifestyles (use of tobacco and alcohol, inadequate diet, lack of physical activity) and exposure to cancerogenic agents (5).

Studies have shown that the incidence of cancer as a cause of factors associated to quality of life components that interfere, extrinsic factors such as obesity,arehaving an impact on the prevalence of cancer (6). Obesity is a characteristic that has been researched on and has been demonstrated as an important factor (7); it is defined as "an excess of totalbody fat or in the adipose tissue. It is produced by an increase in the caloricintake and a de- 
ISSN-PRINT

1794-9831

E-ISSN 2322-7028

Vol. 17 No. 1

Ene - Abr 2020

Cúcuta, Colombia crease in the caloric output" (8). In "a meta-analysis of descriptive studies, it was found that the risk of breast cancer increases when there is an increase of $5 \mathrm{~kg} / \mathrm{m} 2$ in the BMI in this group of women" (9), this means that research should be done for this purpose.

Also,a relationship between obesity and an increase of cardiovascular abnormalities has been determined (10), which complicates even more the prevalence of cancer. Therefore, knowledge about possible cardiovascular risks allows to put special attention toward prevention, as well as health promotion for women with breast cancer. When the health parameters are previously known it is observed that these can be affected due to the presence of high blood pressure, which is conceptualized as a "chronic diseasethat is characterized by a constant elevation of the systolic blood pressurehigher than $140 \mathrm{~mm}$ $\mathrm{Hg}$ and/or diastolic blood pressure higher than $90 \mathrm{~mm}$ Hg" (11). The presence of high blood pressure merits to be evaluated due to its association to cardiovascular diseases and as a possible risk factor for women with breast cancer.Another important parameter to consider which can affect the quality of life is the blood sugar level, since it has been considered that at the moment of diagnosis for breast cancer, $16-20 \%$ (12) of the patients have diabetes, a relevant factor for this study, given that diabetesas well as breast cancer, is a disease that has major consequences in the quality of life of women, especially if the lifestyle practices are considered, making diabetes a globally predominant disease(13).

On the other hand, quality of life has been worked on from subjectivity and according to the definition given by Estrada et al. (14), is "a vague, ethereal, versatile and multifactorial concept, whose main definitions have been given from medical, philosophical, economic, ethic, sociological, political and environmental knowledge", a concept that allows to associate aspects from the person related to their nutrition, interpersonal relationships, physical activities, etc. If diverse reviews are considered about the aspects abovementioned, diverse literature can be found about quality of life and its evaluation, which has given riseto make evaluations that are specific for each disease, for example the questionnaire for breast cancer, which has been supported by various associations for its viability and use (15).

For this reason, measurement of quality of life has evolved as well as its concept; this way, diverse evaluation systems have been created, being medical associations the ones that have generated progress regarding specific evaluation standards according to the pathology of each person. An evaluation was validated in diverse countries, it is known as "scale and questionnaire from the European Organization for Research and Treatment of Cancer (EORTC) including the general questions about quality of life and the specific items of quality of life in breast cancer (QLQ-BR23)" (16). In this evaluation the general health status, and the physical, emotional, cognitive and social functions are evaluated; also, symptoms are included and their level of limitation regarding quality of life.

\section{Objectives}

\section{General objectives.}

Identify the quality of life and its association with health parameters in breast cancer women survivors in Popayan Colombia, 2017.

\section{Specific objectives}

- Determine the sociodemographic characteristics of the population.

- Determine the incidence of overweight and obesity.

- Evidence the presence of alterations in the health parameters related to blood pressure and blood sugar.

- Establish what aspects of quality of life are affected in women with breast cancer in the city of Popayan.

\section{Materials and Methods}

The present study had an analytic cross-sectional quantitative focus, with correlational-descriptive character. The sample was made with a group of women from oncology centers in the city. 39 women who are breast cancer survivors met the inclusion criteria, who accepted to participate voluntarily. The objectives and the procedures of this research were explained to this representative group.

The criteria for selection were: having a medical diagnose indicating that the woman was a breast cancer survivor in any of its stages; not presenting symptoms of infectiousnor inflammatory processes in the days of evaluation; being over the age of 18; and last, accepting and signing an informed consent. For this study, women with mental health alterations or by indication of the oncologist were excluded.

The evaluations were performed in the laboratory of functional evaluation and physical conditioning in the 
Institutes of Higher Education (IHE), in charge of trained personnel, who made an interview to compile the preliminary information that was necessary and to select the sample according to the inclusion criteria; subsequently, phone calls were made to apply the different evaluations and measurements of the variables for the study.

To evaluate the anthropometric variablesthere were trained personnelfor the evaluation, according to the recommendations from the International Society for the Advancement of Kinanthropometry (17), considering that the participant must have had their shoes off and with light clothing. For the measurements of weight and body mass index, a mechanic scale with a measuring rod(brand detecto, Ref. RGTA-200) with $0,1 \mathrm{~cm}$ of precision and a capacity for $200 \mathrm{~kg}$. With these data, the corresponding formula to the BMI was applied (18) and the data was grouped according to the indications of the WHO (19).

On the other hand, a sample of blood sugar was taken after at least 8 hours of fasting; a capillary sample was taken, considering the glucose levels when fasting of $\geq 110 \mathrm{mg} / \mathrm{dl}$; with a glucometer and reactive test strips brand EasyGluco ${ }^{\circledR}$ and were classified according to the standards of the American Diabetes Association (20).

Forthe measurement of blood pressure, a digital blood pressure meter(Omron brand) was used. The blood pressure was measured in the right arm, in a seated position, allowing the patient to rest for 20 minutes. The blood pressure was taken in three occasions and the results were placed in the classification tables for blood pressure (21). The ranges obtained which were considered, correspond to the systolic pressure with values of $\geq 140$ $\mathrm{mmHg}$ and the diastolic pressure with a value of $\geq 90$ $\mathrm{mmHg}(22)$. The classification is defined according to the Colombian guide for the diagnosis and treatment of high blood pressure (HBP) (23).

The punctuations in each of the domains and individual items were calculated according to the instructions given by the EORTC (24) in its scoring manual for scales, from which 23 aspects are evaluated distributed in functional dimensions such as: body image, sexual function, sexual pleasure and perception of the future. Among the present symptoms, the questionnaire asks about the secondary effects of the systematic therapy, symptoms around the breast area and discomfort due to hair loss. The scoring started from 1 corresponding to "not at all" and 4 corresponding to "a lot". For the functional scales, a higher value corresponds to a "better" functional state, expect in the scales of sexual function and sexual pleasure, where the scores were inverse. In the symptoms scale a higher value refers to the existence of a symptomatology and therefore a "worse" state of health.

The analysis of the information was made with the program Statistical Package for Social Science ${ }^{\circledR}$ software, 20th version (SPSS; Chicago, IL, USA). The distribution of the sample was analyzed with the Shapiro-Wilk tests, since the sample had less than 50 patients. The results were expressed as means \pm , standard deviations (SD) or percentages, as appropriate. The significance was obtained through a chi square test with a $p$ value of $<0.05$ and a correlation of the variables was established using the Pearson correlation coefficient; partial correlations were used to evaluate the relationship between each of the anthropometric variables and the blood sugar and blood pressure values obtained.

Forthe ethical, legal aspects: the stated in the Helsinki Declaration (25) and the Resolution 8430 of the Ministry of Health and Social Protection of Colombia (26) were considered for the research. The support group was provided with talks about the ethical aspects and howto assume the approach and encounters; followed by presenting the project to the women, with previous approval from the ethics committee (ID. 4495) from the University of Cauca. Likewise, the population was guaranteed with intimacy protection, confidentiality and the right of anonymity of the provided data from the evaluations, considering the decreed in the Law 1581 of 2012; also, the study with minimal risk of injury for the patients was considered.

\section{Results}

The population of women who are survivors of breast cancer presented an average age of $48,52 \pm 11,75$ years, $54 \%$ of the population had a marital status: married (41\%) followed by divorced (38,5\%). The predominant diagnosis was breast cancer according to its stage, Ilb $(28,2 \%)$, Ib $(25,6 \%)$, IIa $(23,1 \%)$ and the rest had percentages of less than $10 \%$. The evaluation of the anthropometric parameters in relation to the BMI allowed to determine that $48 \%$ of the population of study presented overweight, followed by normal weight $(28,2 \%)$.

Regarding blood pressure, it can be observed that women reported normality values in $43,6 \%$ of the population; the distribution of this item according to the marital status can be analyzed in graphic 1 . 
ISSN-PRINT

1794-9831

E-ISSN 2322-7028

Vol. 17 No. 1

Ene - Abr 2020

Cúcuta, Colombia

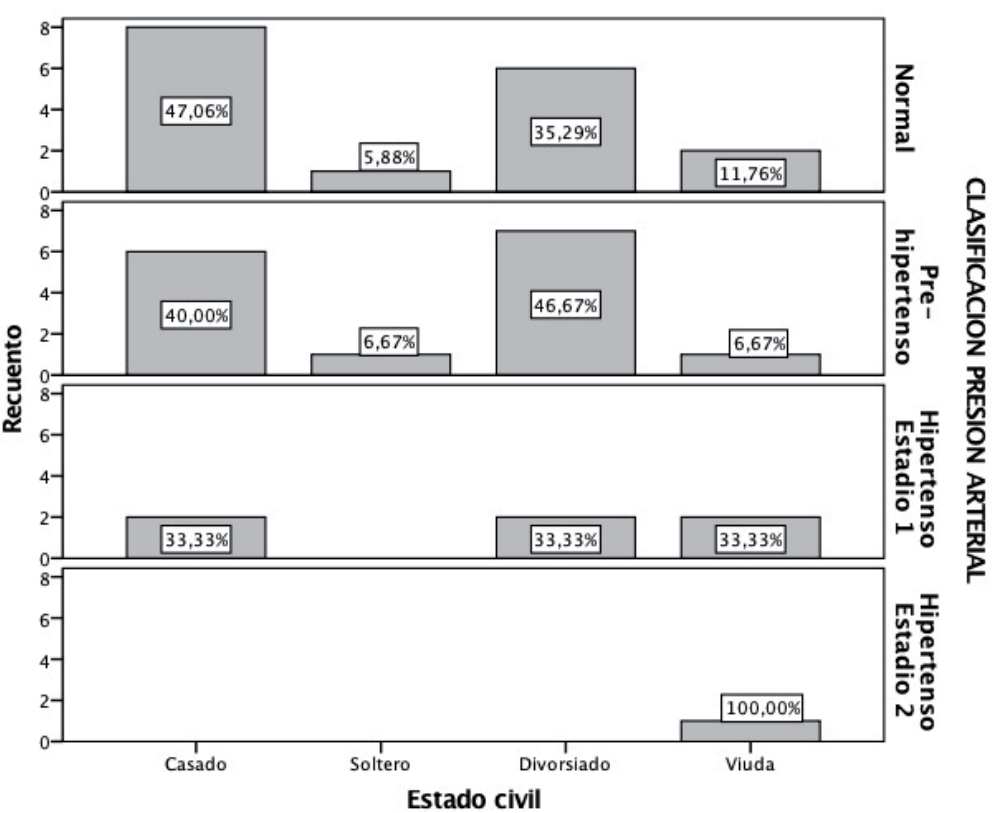

Graphic 1: Blood pressure classification in women

Source: Elaborated by the authors

When evaluating the blood sugar levels, the study was able to determine the predominance in the indicators of the parameter for prediabetes in $59 \%$ of the population, followed

by normalblood sugar levels with $38.5 \%$, as seen in graphic 2 , the distribution is shown according to the marital status.

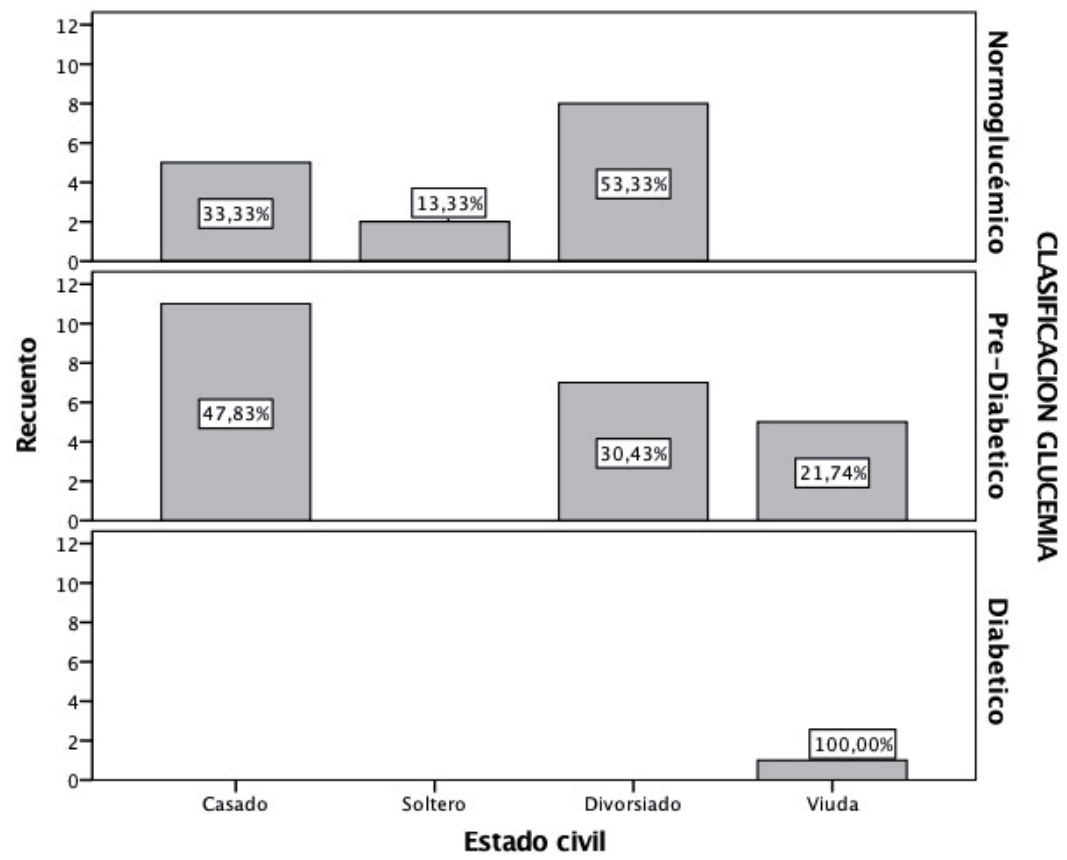

Graphic 2: Blood sugar levels in the population Source: Elaborated by the authors

In table 1 the quality of life can be visualized, evaluated with the questionnaire QLQ- BR23, obtaining elevated measurements for body image and sexual function; while the dimensions of sexual pleasure and perception of the fu- ture showed intermediate measurements. It was observed that the whole symptomatology component showed lowed scores. 
Table 1: Parameters of the population measured with the questionnaire EORTC QLQ-

E-ISSN 2322-7028 BR23

\begin{tabular}{lccc}
\hline EORTC QLQ-BR23 & Mean & Standard Deviation & P \\
\hline Body image & 98 & 1,52 & 0,000 \\
Sexual function & 100 & 1,109 & 0,000 \\
Sexual pleasure & 65,75 & 0,489 & 0,000 \\
Perception of the future & 66,67 & 0,536 & 0,000 \\
Effects of the systematic treatment & 9,59 & 1,788 & 0,000 \\
Breast symptoms & 11,64 & 1,857 & 0,000 \\
Arm symptoms & 7,95 & 1,503 & 0,000 \\
Hair loss concern & 2,67 & 0,955 & 0,000 \\
\hline
\end{tabular}

Vol. 17 No. 1

Ene - Abr 2020

Cúcuta, Colombia

Source:Elaborated by the authors

The results obtained from the variables allowed to evidence astatistically significant relationship of $p<0.05$, reflec-

ting moderate relationships, as established in table 2 .

Table 2: Significant variables for the study

\begin{tabular}{cccc}
\hline & Correlation & Significance & Type of Correlation \\
\hline Blood sugar / Sexual Function & 0,51 & 0,001 & Moderate \\
Blood pressure /Arm symptoms & 0,56 & 0,047 & Moderate \\
Stage / Imagen corporal & 0,41 & 0,009 & Moderate \\
Blood Sugar / Sexual pleasure & 0,41 & 0,049 & Moderate \\
\hline
\end{tabular}

Source:Elaborated by the authors

\section{Discussion}

Breast cancer is one of the predominant diseases with a high tendency of mortality globally, making it a relevant subject for its study, even more when its associated to aspects such as quality of life and health parameters like blood sugar and blood pressure. From this perspective, this study was able to dimension aspects that can be relevant when taking care of a patient with these pathologies, which allows to compare it with other international studies (27), where it is determined that cancer is associated to other health problems; therefore, it must be a motive of research as an interdisciplinary work.

From the socio-demographic aspects the study was able to evidence that women showed an average age of 48 years, which is a similar result for the epidemiological profile suggested by the American Breast Cancer Society(28), which determines that the approximate age of diagnosis is between the ages from 45 to 50 . Analyzing from the endocrinological perspective it is suggested that the age of diagnosis is related to relevant changes in the woman in the stage of pre-menopause and menopause (29), where the hormonal charge produces a mitogen effect in the mammary gland cells, influencing in the incidence of the pathology. On the other hand, a hypothesis that relates cancer presence with the living standards of the women population (30) has been established, inferring that there is a direct correlation between the level of poverty with advanced cases of breast cancer (31), a fact that merits to be studied and also generate both preventive and promotion health actions in all the socioeconomic spheres.

Another important parameter which relates to breast cancer, is the marital statues and the support the woman has when facing this disease. It must be noticed that according to the study, $41 \%$ of the women were married, while $38.5 \%$ were divorced, a similar report found by Pineda et al. (32), who established that the support women with breast cancer require is mainly derived from a family member, which allows to encourage healthy and mentally stable environments toward the symptoms manifested such as depression and anxiety (33).It was also found that divorced women tend to generate, due to their condition, factors such as mentioned in other researches (34), that are associated to health detriment and a low level in the immunologic system, caused by a lack of emotional support, resulting in the development of the disease (35). Considering the abovementioned, it is important 
ISSN-PRINT

1794-9831

E-ISSN 2322-7028

Vol. 17 No. 1

Ene - Abr 2020

Cúcuta, Colombia to create healthy environment and support that the patient must receive when facing this pathology, which is typically associated to death (36).

One of the relevant indicators when intervening a population are the ones related to the anthropometric indicators, which allow to determine pathologies that affect the health of the population. For the women population it was found that the values were of overweight for the BMI, a situation that is similar to the one demonstrated by Sifuentes et al. (37), who mention overweight and obesity as health risk factors, since the concentration of triglycerides, low density lipoproteins and insulin sensibility play an important role when estimating breast cancer, as indicated by Godinho et al. (10). Thus, the findings of this study generate and alert; according to diverse reports "the proposed mechanism for the development of cancer seems to be one of the three ways, the main ones being estrogen, insulin and leptin" (27). This factdeserves studies of wider cohort since most of the studied population presented stages of prediabetes and diabetes, which according to the findings of Otto Warburg in 1924, the glycolysis is one of the main energetic ways for cancer cells, which favor their growth and reproduction (38).

Regarding blood pressure it was found that mostof the studied population presented normal levels in the measurements, favoring an important aspect in the health process; however, it must be considered as constant evaluation value due to its closeness to the mammary gland; when an increase is observed, it can be associated to metabolic syndrome and as expressed before, this factor has effects that can stimulate cancer (5). Another important aspect to consider is reported by Milan et al. (39), who indicate that the medicine used for the treatment of cancer "interacts with the VEGF (Vascular endothelial growth factor) which are the medicines most frequently related to hypertension. However, many retrospective studies have suggested a relationship between the antihypertensive drugs and the risk of cancer, generating a great public concern" and therefore the necessity to effectuate follow up studies.

In regard to the quality of life, the study was able to determine that both body image and sexual function are altered, which is supported by other studies (40), inferring that in breast cancer, the social stigma related to personal issues, generates relevant changes on the woman that are related to their body image, affecting their interpersonal relationships, especially with their partner (41). Similarly, an association was evidenced between the variables and the levels of blood sugar, body mass index and blood pressure, allowing to explain that the functionality component has a moderate relationship with physical parameters as biochemicals related to the health of the woman. On the other hand, the symptomatologic component allowed to identify low measurements, which can go hand in hand with the latest pharmacological advances that make diminish the symptoms on the woman, a factor that previously caused great preoccupations and limitations with everything related to symptomatology reported for breast cancer (42).

\section{Conclusions}

The anthropometric parameters of the women population presented values of overweight, with is a warning sign that must be considered to prevent the incidence and possible complications. The values associated to blood pressure and blood sugar had a normal tendency, indicating that a follow up must be made to prevent possible risks, as a way for prevention. Regarding quality of life, the study was able to determine that body image as well as sexual function, presented high scores, allowing to establish for future support members, better support for patients to strengthen self-confidence and their relationships with themselves; also, aspects associated to symptomatology must be monitored. Generally, the study was able to estimate that interdisciplinary intervention for the population with breast cancer is necessary, since not only attention from the oncology team allows to optimize the quality of life of the patients, but also the quality of life of their families.

\section{Acknowledgements}

To all the personnel that was needed to do this research, as well as to the women who contributed and allowed us to understand better breast cancer; also special thanks to the University of Cauca and the vice-rector for research and their financial support.

\section{Conflict of interests}

The authors do not manifest any type of conflict of interests. 


\section{Bibliographic References}

1. Wellburn S, Ryan CG, Azevedo LB, Ells L, Martin DJ, Atkinson G, Batterham AM. Displacing sedentary time: Association with cardiovascular disease prevalence. Med Sci Sports Exerc. 2016;48(4):641-7.

2. Escobar K, Ruidíaz Gomez K. Desigualdad social y obesidad en la población adulta colombiana. Arch Med. 2017;17(2).

3. Navarro Ibarra M, Caire Juvera G, Ortega Vélez MI, Bolaños Villar AV, Saucedo Tamayo M. Influencia de los factores reproductivos, la lactancia materna y la obesidad sobre el riesgo de cáncer de mama en mujeres mexicanas. Rev Nutrición Hospitalaria. 2015;32:291-298

4. Yépez MC, Jurado DM, Bravo LM, Bravo LE. Tendencia de la incidencia y mortalidad por Cáncer en Pasto, Colombia. 15 años de experiencia. Colomb Med. 2018;49(1).

5. Romero Figueroa MDS, Diaz Montiel JC, Avila Jiménez L, Duarte Mote J, Colín Ferreyra MDC, Montiel Jarquín ÁJ. Dietary patterns of Mexican patients with breast cancer and obesity. Nutr Clin y Diet Hosp. 2017; 37(4):93-100.

6. Reyes Barretero DY, Cruz Castillo AB, Jaimes Alpízar E, Carmona Vilchis J, Cabrera Galeana PA, et al. Prevalencia de sobrepeso y obesidad de acuerdo al Índice de Masa Corporal y el porcentaje de grasa en pacientes con cáncer de mama. Nutr clínica y dietética Hosp [Internet]. 2016[consultado 27 de agosto de 2019]; 36(3):10-3. Disponible en: https://dialnet.unirioja.es/servlet/articulo?codigo=5638676

7. Quintana López V, Díaz López K, Caire Juvera G. Intervenciones para promover estilos de vida saludables y su efecto en las variables psicológicas en sobrevivientes de cáncer de mama: revisión sistemática. Nutr Hosp. 2018;35(4):979-92.

8. Delgado Floody P, Caamaño Navarrete F, Osorio Poblete A, Jerez Mayorga D. Variaciones en el estado nutricional, presión arterial y capacidad cardiorrespiratoria de obesos candidatos a cirugía bariátrica: Beneficios del ejercicio físico con apoyo multidisciplinar. Nutr Hosp. 2016;33(1):54-8.

9. QuirogaMorales LA, SatMuñoz D, MartínezHerrera BE, AlcántaraCadillo RR, MacíasLópez GG, et al. Obesidad y adipocitocinas en cáncer de mama y enfermedad mamaria benigna. Rev Med Inst Mex Seguro Soc [Internet]. 2018 [consultado 27 de agosto de 2019];56(3):246-54. Disponible en: https:// www.medigraphic.com/cgi-bin/new/resumen.cgi?IDARTICULO $=84070$

10. Godinho Mota JCM, Anusca Martins K, Vaz Gonçalves L, Mota JF, Ribeiro Soares L, Freitas Junior R. Visceral adiposity increases the risk of breast cancer: a case-control study. Nutr Hosp. 2016; 33(2):451-8.

11. Valle EQ, Herrera AS, Rica UDC. Efecto agudo del orden de ejecución de ejercicios contra resistencia sobre la presión arterial en jóvenes estudiantes normotensos Acute effect of the order of execution of resistance exercises on blood pressure in normotensive young students. Retos. 2017; 32:68-71.

12. Jarvandi S, Pérez M, Schootman M, Jeffe DB. Pre-Existing Diabetes in Early Stage Breast Cancer Patients is Associated with Lack of Improvement in Quality of Life 2 Years After Diagnosis. Int J Behav Med. 2016;23(6):722-9.

13. Ponce de Leon S, Ferran Fernandez Y, Portal Moreno R. El cáncer, un desafío común. De la percepción pública a la responsabilidad social. Rev Comun y Salud. 2016; 6:42-53.

14. Estrada A, Cardona D, Segura ÁM, Chavarriaga LM, Ordóñez J, Osorio JJ. Calidad de vida de los adultos mayores de Medellín. Biomédica [Internet]. 2011 [consultado 27 de agosto de 2019];31(4):492502. Disponible en: http://www.revistabiomedica.org/index.php/biomedica/article/view/399

15. Irarrázava1 ME, Rodríguez PF, Fasce G, Silva FW, Waintrub H, et al. Calidad de vida en cáncer de mama: validación del cuestionario BR23 en Chile. Rev Med Chile. 2013;141:723-34.

16. SánchezPedraza R, SierraMatamoros AF, LópezDaza DF. Validación colombiana de la escala FACTB para medir la calidad de vida de pacientes con cáncer de mama. Rev Colomb Obstet Ginecol. 2012;63(3):196-206. 
ISSN-PRINT

1794-9831

E-ISSN 2322-7028

Vol. 17 No. 1

Ene - Abr 2020

Cúcuta, Colombia
17. MolanoTobar NJ, MolanoTobar DX, OrdoñezFernández, M. Cambios antropométricos y asociación del nivel de actividad física en docentes universitarios. Rev. cienc. cuidad. 2017; 14(2):38-50.

18. Gualterosa JA, Torresa JA, UmbarilaEspinosaa LM, RodríguezValeroa FJ, RamírezVélez R. Una menor condición física aeróbica se asocia con alteraciones del estado de salud en niños y adolescentes de Bogotá, Colombia. Endocrinol y Nutr. 2015;62(9):437-46.

19. Rodríguez F, Espinoza Oteiza L, Galvez Carvajal J, Macmillan Kuthe P. Estado nutricional y estilos de vida en estudiantes universitarios de la Pontificia Universidad Católica de Valparaíso. Univ y Salud. 2013;15(2):123-35.

20. Real de Asua D, Parra P, Costa R, Moldenhauer F, Suarez C. Evaluation of the impact of abdominal obesity on glucose and lipid metabolism disorders in adults with Down syndrome. Res Dev Disabil. 2014;35(11):2942-9.

21. Chobanian A V, Bakris GL, Black HR, Cushman WC, Green LA, Izzo JL, et al. Séptimo informe del comité nacional conjunto en prevención, detección, evaluación y tratamiento de la hipertensión arterial. Hypertension. 2003;42:1206-52.

22. Power C, Pereira SMP, Law C, Ki M. Obesity and risk factors for cardiovascular disease and type 2 diabetes: Investigating the role of physical activity and sedentary behaviour in mid-life in the 1958 British cohort. Artherosclerosis. 2014;233:363-9.

23. Argemiro Fragozo, M.; Aschner P.; Pinzón, JB, Gómez E. Guía Colombiana para el diagnóstico y tratamiento de la Hipertensión Arterial. Revista Colombiana De Cardiología. 2009;16.

24. Irarrázaval ME, Rodríguez P, Fasce G, Silva F, Waintrub H, et al. Calidad de vida en cáncer de mama: validación del cuestionario BR23 en Chile. 2013;141 (6):723-734

25. Declaración de Helsinki. Declaracion de Helsinki. Principios éticos para las investigaciones médicas en seres humanos. Tokio-Japón: Asociación Médica Mundial; 1975.

26. Ministerio de Salud y Protección Social Colombia. Resolución 8430. 1993.

27. Inamdar P, Mehta G. Correlation Between Obesity and High Density Lipoprotein Cholesterol (HDLC) in Breast Cancer Patients of Southern Rajasthan. Indian J Surg Oncol. 2011;2(2):118-21.

28. Pereira DA, Brandao Souza C, Amaral Musso M, Vieira Calmon M, Costa Neto S, et al. Quality of life of women with pre-and post-operative breast cancer. Invest Educ Enferm. 2017;35(1):109-19.

29. Finck C, Barradas S, Zenger M, Hinz A. Quality of life in breast cancer patients: Associations with optimism and social support. Int J Clin Heal Psychol. 2018;18:27-34.

30. Agudelo BM. Determinantes sociodemográficos del acceso a la detección del cáncer de mama en México: una revisión de las encuestas nacionales. Salud Colect [Internet]. 2013 [consultado 27 de agosto de 2019];9(1):79-90. Disponible en: http://www.scielo.org.ar/scielo.php?script=sci_arttext\& $\mathrm{pid}=\mathrm{S} 1851-82652013000100007$

31. Gutiérrez C, Alarcón E. Nivel de pobreza asociado al estadio de gravedad del cáncer ginecológico. An la Fac Med. 2008;69(4):239-43.

32. Pineda Higuita S, Andrade Mosquera S, Montoya Jaramillo Y. Factores asociados a la calidad de vida en mujeres con cáncer de mama, Medellín 2013. Rev Gerenc Polit Salud. 2017;16(32):85-95.

33. Jakobsen MD, Braaten T, Obstfelder A, Abelsen B. Self-Reported food hypersensitivity: Prevalence, Characteristics, and Comorbidities in the norwegian women and cancer study. PLoS One. 2016;11(12):1-13.

34. Miguel PB, Pascua IR, Sánchez CM. Contexto Familiar Y Adicción Al Juego. Factores Que Determinan Su Relación. Heal Addict / Salud y Drog. 2016;16(2):81-91.

35. Eberhardt AC, Bezerra SL. Qualidade de vida e a cirurgia em cancro da mama: revisão narrativa da literatura. Rev CES Psicol. 2017;10(1):35-47.

36. MolanoTobar NJ, Vélez Varela PE. Percepción acerca del cáncer de mama en un grupo de mujeres 
de un hospital en Popayán, Colombia. Rev MHSalud® [Internet]. 2017 [consultado 27 de agosto de 2019];13(2):1659-97. Disponible en: www.una.ac.cr/salud\%0Ahttp://www.revistas.una.ac.cr/mh$\underline{\text { salud }}$

37. SifuentesÁlvarez A, CastañedaMartínez LY, LugoNevares M, ReyesRomero MA. Factores de riesgo asociados con el cáncer de mama en mujeres del estado de Durango, México. Ginecol Obs Mex [Internet]. 2015;83(11):662-9. Disponible en: https:/www.medigraphic.com/cgi-bin/new/resumen. cgi?IDARTICULO $=61853$

38. Duarte M, Romero F, Espinosa L, Sánchez R. Diabetes y cáncer ¿es real la asociación? Med Int Mex. 2016;32(3):318-29.

39. Milan A, Puglisi E, Ferrari L, Bruno G, Losano I, Veglio F. Arterial hypertension and cancer. Int J Cancer. 2014;134(10):2269-77.

40. PorrasKusmanic N, NorrisSquirell F. Cáncer de mama con metástasis cutánea. Dermatol Rev Mex. 2017;61(2):153-7.

41. Fortes LS, Cipriani FM, Coelho FD, Paes ST, Ferreira MEC. A autoestima afeta a insatisfação corporal em adolescentes do sexo feminino?. Rev Paul Pediatr [Internet]. 2014 [consultado 27 de agosto de 2019]; 32(3):236-40. Disponible en: http://dx.doi.org/10.1590/0103-0582201432314

42. Chottanapund S, Van Duursen MBM, Navasumrit P, Hunsonti P, Timtavorn S, Ruchirawat M, et al. Anti-aromatase effect of resveratrol and melatonin on hormonal positive breast cancer cells co-cultured with breast adipose fibroblasts. Toxicol Vitr. 2014;28(7):1215-21. 